\title{
Techno-Economic Evaluation of Solar Irrigation Plants Installed in Bangladesh
}

\author{
Najmul Hoquea, Amit Roya*, Mohd. Rafiqul Alam Bega and B. K. Das ${ }^{b}$ \\ ${ }^{a}$ Department of Mechanical Engineering, Rajshahi University of Engineering \& Technology, Bangladesh \\ ${ }^{b}$ School of Engineering, Edith Cowan University, Australia
}

\begin{abstract}
In the summer season, irrigation sector in Bangladesh suffers a lot due to the country wide electricity crisis. Solar pump offers a clean and simple alternative to the conventional fuel fired engine or grid electricity driven pump in this regard to resolve the issue. In this paper, the techno-economic analyses of solar irrigation plants installed in Bangladesh are evaluated. It was observed that systems were running around $70 \%$ to $80 \%$ of the rated power which was quite acceptable. A $10 \mathrm{hp}$ pump was able to pump 600 liter of water per minute which was also satisfactory to irrigate the land. Average operating time was found to be 8 hour/day. It was found that the overall efficiency of the systems were in between $11.39 \%$ to $16.52 \%$ whereas the typical average value of lit/Wp/year was 9200 . On the other hand, the cost of irrigation to cultivate paddy in 0.161 hectares' land for one season was 1,750 BDT by solar irrigation which was found to be lower than that of other available modes. This charge for grid electricity based irrigation was about 3,000 to 3500 BDT per 0.161 hectares' and 2,300 to 2,600 BDT per 0.161 hectares' for diesel engine based irrigation. According to the current financial scheme (15\% equity investment, $35 \%$ credit support and remaining $50 \%$ from government through IDCOL) the average value of payback period was 5.43 years, NPV in the range from 7 to $15 \%$ and IRR was $18 \%$. By considering $100 \%$ equity investment, however, these projects were not economically attractive. The payback period for this case was about 18 years. Study also revealed that each solar irrigation plant reduces $42.8 \mathrm{~kg}$ of CO2 emission per day compare to diesel engine operated pump and $2566.24 \mathrm{~kg} /$ day compared to grid electricity operated pump. A comprehensive effort from the Government as well as from all the stakeholders is required for further expansion of solar irrigation plants in Bangladesh.
\end{abstract}

Keywords: Renewable Energy, Solar pumping, Irrigation, Techno-economic analysis, Bangladesh

Article History: Received Sept 05, 2015; Received in revised form Dec 15, 2015; Accepted February 2, 2016; Available online

How to Cite This Article: Hoque, N., Roy, A., Beg, M.R.A. and Das, B.K. (2016) Techno-Economic Evaluation of Solar Irrigation Plants Installed in Bangladesh. Int. Journal of Renewable Energy Development, 5(1), 73-78.

http://dx.doi.org/10.14710/ijred.5.1.73-78

\section{Introduction}

The continuous depletion of fossil fuel reserves and growing awareness of their environmental impact promote the development of more sustainable energy supply options. These issues have triggered the researchers to find out the sustainable sources all over the world (Mekhilef et al, 2011; Mahlia et al, 2012). Bangladesh government has its own vision pertain to renewable energy, most importantly towards the utilization of solar energy resources. The country is situated between $20^{\circ} 34^{\prime}-26^{\circ} 38^{\prime}$ north latitude and $88^{\circ}$ $01^{\prime}-92^{\circ} 41^{\prime}$ east longitude which is ideal for solar energy utilization (Roy et al, 2015). The average solar radiation values within the country vary between 4 and
$6.5 \mathrm{kWh} / \mathrm{m}^{2} /$ day (Hoque and Kumar 2013). At the same time, Bangladesh is primarily an agrarian country. The total contribution of agriculture sector to GDP is $19.29 \%$ and crop sector to GDP is $13.44 \%$. Around $47.5 \%$ of total man power relies in agriculture sector. This agriculture sector has a huge impact in generating employment, alleviate poverty and provide food security to the country. The total cultivable land in Bangladesh is 8.52 million hectare in which the total cropped area is 14.943 million hectare (Bangladesh Agriculture at a Glance). These large amount of lands are cultivated by 2,66,000 irrigation pumps which are being operated by grid electricity or diesel generators. Grid electricity based irrigation pumps consume about $1300 \mathrm{MW}$ of electricity which is approximately $25 \%$ of

"Corresponding Author: +88-01723559846; fax: +880721-750319

Email: royamit.me@gmail.com 
Citation: Hoque, N., Roy, A., Beg, M.R.A. and Das, B.K. (2016) Techno-Economic Evaluation of Solar Irrigation Plants Installed in Bangladesh.. Int. Journal of Renewable Energy Development, 5(1), 73-78, doi.org/10.14710/ijred.5.1.73-78

P a g e 74

the total production of the country (IDCOL. Infrastructure Development Company Limited Bangladesh). The electricity access to developing countries is a big challenge which include ever increasing demand-supply gap, crumbling electricity transmission and distribution infrastructure, high cost of electricity, a variety of barriers in harnessing renewable energy resources for electricity generation (Hayden ; Legros and Organization 2009). At the moment, it is impossible for Bangladesh to supply the desire amount of electricity for irrigation as the country experience unmanageable gap between supply and demand of electricity. Load shedding seems intolerable especially in the summer season during which there is huge demand of electricity to irrigate the land. At present the electricity generation capacity in Bangladesh is $6500 \mathrm{MW}$ (Bangladesh Power Development Board (BPDB)). Only about $47 \%$ of the total population of the country has access to grid electricity. This unavailability of electricity decreases the production of foods and also cut the growth of GDP. Beside grid electricity, diesel generators are the other options to operate the irrigation pump. In Bangladesh, around 0.9 million tons of diesels are used per year to operate about 1.34 million diesel run irrigation pumps (Islam et al, 2008). To minimizes the energy crisis and also for increasing price of petroleum fuel, it is a crying need to explore alternative energy source for irrigation purposes. Solar power irrigation system brings a new era of irrigation in Bangladesh in this regard.

Agriculture plays an important role in Bangladesh's economy and employs 45 percent of the country's workforce. Water has been a critical lifeline for farmers as a day without proper irrigation can damage crop quality and yields. Traditionally, Bangladeshi farmers have relied on expensive diesel- or electricity-powered irrigation pumps(Bangladesh Agriculture, 2015). There are 1.34 million diesel pumps and 270,000 electric-run pumps used for irrigation. Every year, diesel pumps consume 1 million tons of diesel worth $\$ 900$ million (Lipu and Jamal 2013). This is a costly amount, which the government subsidizes at the expense of other agricultural innovations. Transportation of diesel to crop fields is difficult and the supply can be inconsistent. Farmers are often dependent on middlemen, who charge higher diesel prices during peak irrigation and cropping season and drive farmers further into financial difficulty. Diesel pumps also frequently break down, have high maintenance costs, and pollute the environment (Solar-Powered Pumps Reduce Irrigation Costs in Bangladesh).

There are more than 38 solar irrigation pumps are already installed in the country and other 114 pumps are in under consideration. There is also a plan to install 1550 solar irrigation pumps within the year 2017. The Bangladesh government has a vision to generate $10 \%$ of its total power by renewable sources within the year 2020 (Power Division. Ministry of Power). To fulfill this vision, solar electricity can play an important role. In the solar irrigation system solar panel is used to produce dc current and then converted to ac current to run the motor. Both solar tracking or without solar tracking system is used in the solar panel. This process is easy and environment friendly as well. To replace the fossil fuels and to use renewable energy sources, IDCOL with the help of World Bank, KFW, KOICA, JICA, ADB, USAID, GPOBA and Bangladesh Climate Change Resilience Fund (BCCRF) are supporting to set up these particular projects in the rural areas. Finally, at the users level, Grammen Shakti, Jagorani Energy, ARS Bangladesh, REB and Electro Solar Power Ltd install and maintain the solar irrigation projects. Because of its high installation cost the payback period of this kind projects are too high to achieve the return. To minimize the payback period and to make the project viable still lot of barriers and challenges to be overcome.

The number of published paper regarding solar irrigation plant in Bangladesh is very few as this concept is quite new in the country. That is why, to understand the feasibility of solar irrigation plants in Bangladesh, the technical and economic analysis are considered in this study. Mekhilef et al, (2013) reviewed the application of solar energy in agricultural sector and found that photovoltaic systems would be the suitable options in agricultural application and especially for the distant rural area since the solar system offers maintenance free and has no impact on the environment. Purohit (2007) studied the financial evaluation of renewable energy technologies for water pumping in India. This study developed a simple framework and estimated unit cost of water and unit cost of useful renewable energy.

Odeh et al, (2006) studied on the economic viability of a photovoltaic water pumping systems and compared with the diesel engine pumping system and found that off-grid water pumping by using solar energy was a viable option. This paper presents both technical and economic analysis of solar irrigation systems installed in Bangladesh. The subsequent section discusses the methodology used for the study, while the third and fourth section technical and economic analysis. Finally the fifth section discuses about the environmental effect in a brief.

\section{Methodology}

Nine solar irrigation plants from five districts of the country were selected randomly and data collection was carried out by twelve months' period from October 2013 to September 2014 by field visit. All of these projects were installed by the partner organizations (POs) under the support of Bangladesh government through Infrastructure Development Company Limited (IDCOL) and were selected from Jessor, Rajshahi, Naogaon, Bogra and Manikgong districts in Bangladesh. 
Diesel engine and grid electricity are the other modes of irrigation in the rural areas of Bangladesh except solar pumping. The comparison among all types of irrigation was evaluated from the visited areas. To calculate overall efficiency and amount of water per watt peak per year equation (1) and (2) are used respectively.

Calculated overall efficiency $(\eta)=$ Electricity supply to the pump (kWh/day)/Average solar radiation incident on panel $(\mathrm{kWh} /$ day)

Amount of water (L/Wp/Year) = Water supply (L/year)/ Max Wp(W)

All sorts of information based on irrigation were collected by a well structured questionnaire from the farmers and respective beneficiary from the villagers. Secondary data were collected from different official websites and also from various stake holders by interviewing. Economical and brief environmental analyses were accomplished as well as technical with the collected information to reveal the techno-economic analysis of the projects. Under the economic analysis, payback period, NPV and IRR are evaluated where Net Present Value and IRR are calculated by using equation (3), (4) and (5).

$$
\begin{aligned}
& N P V=C O+P V \\
& \text { Net Present value }=\sum \frac{C_{n}}{(1+r)^{n}} \\
& I R R=i 1-N P V 1 \times \frac{i 2-i 1}{(N P V 2-N P V 1)}
\end{aligned}
$$

Where, $\mathrm{CO}$ is the initial investment at period 0 which is a negative figure, $C_{n}$ is the total cash flow, $r$ is the discount rate, NPV1and NPV2 are two different net present values for the interest rates i1 and i2 where NPV1 is positive and NPV2 is negative.

\section{Technical Analysis}

In Bangladesh mainly stand-alone solar irrigation systems are being installed by various public and private organizations. These particular systems mainly consist of PV module, inverter and pump. Since there is no battery, extra energy if available cannot be stored by these systems. Pumping subsystem, while, comprises a submersible pump, a water storage tank and the water distribution pipes. Among the various system it has been observed that usually $7.5 \mathrm{~kW}(10 \mathrm{hp}$ ) pump is operated by $11.20 \mathrm{kWp}$ to $11.84 \mathrm{kWp}$ PV module and $3.7 \mathrm{~kW}(5 \mathrm{hp}$ ) pump is operated by $5.16 \mathrm{kWp}$ to 5.37 $\mathrm{kWp}$ PV module. Normally $10 \mathrm{hp}$ pump is able to pump 600 liter of water per minute. Usually solar panel power is kept much higher than the pump power so that the pump runs frequently when sunlight is available. In Bangladesh, normally $23^{\circ}-24^{\circ}$ inclination angle is maintained for the PV panel as these systems do not use sun tracker. General information regarding visited nine systems is illustrated in table 1 while the visited systems with rated and supply power to the load are shown in Fig. 1. It was observed that systems were running around $70 \%$ to $80 \%$ of rated power which was quite satisfactory.

Table 1

Information about the visited systems

\begin{tabular}{cllll}
\hline $\begin{array}{l}\text { Sr } \\
\text { No. }\end{array}$ & Location & Supplier & $\begin{array}{l}\text { Max Power } \\
(\mathrm{kW})\end{array}$ & $\begin{array}{l}\text { PV Area } \\
\left(\mathrm{m}^{2}\right)\end{array}$ \\
\hline 1 & $\begin{array}{l}\text { Sapahar, } \\
\text { Naogaon, }\end{array}$ & $\begin{array}{l}\text { Grameen } \\
\text { Shakti }\end{array}$ & 11.20 & 81.70 \\
2 & $\begin{array}{l}\text { Godagari, } \\
\text { Rajshahi }\end{array}$ & BREB & 5.16 & 34.80 \\
3 & $\begin{array}{l}\text { Poba, } \\
\text { Rajshahi } \\
\text { Chowgacha, }\end{array}$ & BREB & 5.16 & 34.80 \\
5 & $\begin{array}{l}\text { Jessor } \\
\text { Chowgacha, BD }\end{array}$ & ARS, BD & 11.84 & 79.80 \\
6 & $\begin{array}{l}\text { Jessor } \\
\text { Chowgacha, }\end{array}$ & ARS, BD & 11.84 & 79.80 \\
7 & $\begin{array}{l}\text { Jessor } \\
\text { Barinagar, }\end{array}$ & RSF & 8.40 & 61.30 \\
8 & $\begin{array}{l}\text { Jessore } \\
\text { Muradpur, } \\
\text { Bogra }\end{array}$ & $\begin{array}{l}\text { Electro } \\
\text { Solar }\end{array}$ & 6.00 & 40.59 \\
9 & $\begin{array}{l}\text { Singair, } \\
\text { Manikganj }\end{array}$ & $\begin{array}{l}\text { Electro } \\
\text { Solar }\end{array}$ & 4.20 & 30.60 \\
\hline
\end{tabular}

Source: survey data from field

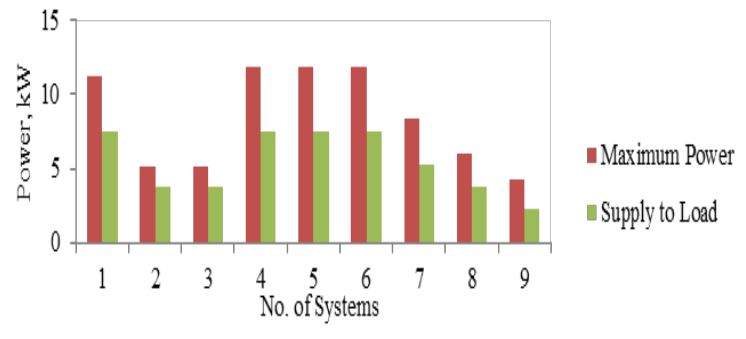

Source: survey data

Figure 1 Power supplied by visited system.

\subsection{Overall Efficiency of solar irrigation systems}

The overall efficiency was calculated by the ratio of the electricity supply to the pump (kWh/day) to the average solar radiation $(\mathrm{kWh} /$ day) incident on the panel given by the equation (1) in methodology section and the average overall efficiency of the visited systems is depicted in Fig. 2. In summer season, the solar radiation value and operating time were maximum so that the overall efficiency was usually higher than other seasons. The maximum overall efficiency was found to be varied between $16.52 \%$ to $11.39 \%$. The overall 
Citation: Hoque, N., Roy, A., Beg, M.R.A. and Das, B.K. (2016) Techno-Economic Evaluation of Solar Irrigation Plants Installed in Bangladesh.. Int. Journal of Renewable Energy Development, 5(1), 73-78, doi.org/10.14710/ijred.5.1.73-78

P a g e 76

efficiency was mostly depended on the load used by the pumps which are broadly described in Table 1 in technical analysis section. In addition, the details information about the calculation are depicted.

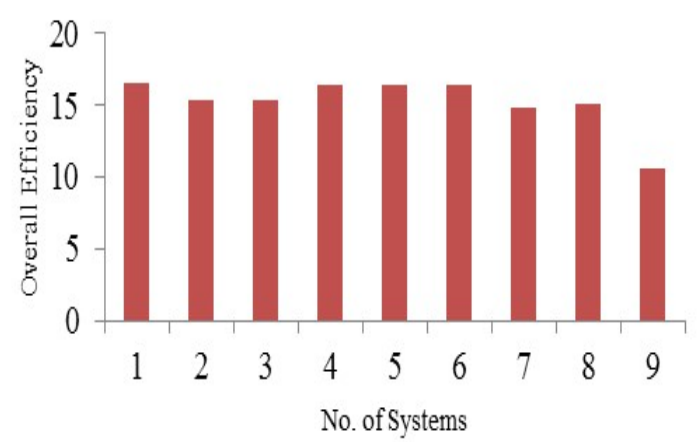

Fig. 2 Overall Efficiency of visited systems.

\subsection{Amount of water pumped per Wp}

In various systems, operating time was varied predominantly due to sunshine. In summer season the average operating time reach 9 to 10 hour while in winter it falls below 7 hours. According to the field visit, the average operating time was 7 hours/day. It was found that the water supply in a year per Wp varied due to the pump capacity and the maximum panel power. Systems were designed to use little bit higher Wp in panel than the requirement due to frequently operate the pump and also to prevent sudden power drop when the sunshine is not sufficient to produce required power. Table 2 presents the flow rate, operating time and water pumped of the visited systems. It was found that the system 1 had the maximum flow rate 550 liter/min and amount of water pumped was around 9679 liter/Wp/year, whereas system 9 had the lowest flow rate 230 liter/min and water pumped around 8395 liter/Wp/year. Amount of water in liter per Wp was determined by the ratio of the water supply per year to the maximum Wp of the panel as shown in equation 2 .

Table 2

Flow rate, operating time and amount of water pumped in various systems

\begin{tabular}{clll}
\hline No. of Systems & $\begin{array}{l}\text { Flow rate } \\
\text { (liter/min) }\end{array}$ & $\begin{array}{l}\text { Operating } \\
\text { time (hr/day) }\end{array}$ & $\begin{array}{l}\text { Amount of } \\
\text { water pump } \\
\text { (lit/Wp/year) }\end{array}$ \\
\hline 1 & 550 & $6-9$ & 9679 \\
2 & 300 & $6-8$ & 9231 \\
3 & 300 & $7-8$ & 9231 \\
4 & 600 & $5-9$ & 9433 \\
5 & 600 & $8-9$ & 9433 \\
6 & 600 & $7-9$ & 9433 \\
7 & 420 & $6-9$ & 9308 \\
8 & 300 & $7-9$ & 8760 \\
9 & 230 & $7-8$ & 8395 \\
\hline Source: survey data. & & &
\end{tabular}

\section{Economic Analysis}

The solar irrigation system introduces an eyecatching way to supply water by low cost compare to conventional irrigation. The economic parameters like NPV, IRR and simple payback period of these systems were investigated to determine the economic feasibility of the project. During the field survey it was estimated that the $10 \mathrm{hp}$ pumps were more suitable for large scale irrigation compare to other pump. By considering a 10 hp pump, the initial cost to setup solar irrigation project (10 hp pump) was varied between $30,00,000$ to $50,00,000$ BDT though its running and maintenance cost was quite low. The life of the project and solar panel was assumed to be 20 years and the durability of submersible pump and inverter was considered 10 years. The total expenses included the installation cost, cost of project area, salary of the operator, repair and maintenance cost and finally cost required for replacement. On the other hand, total income normally had come from the rent of water supply. As per the survey it was found that average 12.84 to 16.1 hectares' land were cultivate under the $10 \mathrm{hp}$ pump in every three season per year. So the total income depends only on the charge to supply water. The average rent to supply water is shown in Table 3.

Table 3

Average charge to supply water per season

\begin{tabular}{cc}
\hline Type of cultivation & Charge BDT/ (0.161 hectare) \\
\hline Paddy & 1750 \\
Wheat & 560 \\
Potato & 560 \\
Onion & 210 \\
Garlic & 210 \\
\hline Source: survey data &
\end{tabular}

It was investigated that the cost to cultivate paddy in 0.161-hectare land for one season was 1,750 BDT by solar irrigation. On the other hand, the same cultivation charge was slightly higher by using grid power or diesel fuel. The charge of grid electricity based irrigation was about 3,000 to 3500 BDT and that was between 2,300 to 2,600 BDT for diesel fuel based irrigation. For the economic analysis the project of Grameen Shakti was considered as a suitable example. The project installation cost was about 50,00,000 BDT. Partner organization (PO) like Grameen Shakti put in 15\% of the project cost as equity and supply water to the farmers as needed, and at an agreed price, during irrigation season. POs order pumps once IDCOL approves technical specifications and install them. After installation, POs can apply for credit and grant financing from IDCOL. IDCOL provides up to $50 \%$ of the project cost as grant financing and $35 \%$ as credit support - the remaining $15 \%$ is covered by PO equity. The economic parameters in terms of payback period, NPV and IRR of the visited systems were calculated and presented in 
Table 4. The simple payback period of the project was 5 years 5 month whereas by considering 100\% equity investment (by POs) the value was not only quite high (about 18 years) but also deplorable.

Table 4

\begin{tabular}{llll}
\multicolumn{3}{l}{ Simple payback, NPV and IRR of visited system } \\
\hline Parameter & Unit & $\begin{array}{l}\text { Respect to } \\
100 \% \\
\text { Equity } \\
\text { investment }\end{array}$ & $\begin{array}{l}\text { Respect to 30\% } \\
\text { equity investment } \\
\text { by GS }\end{array}$ \\
\hline $\begin{array}{l}\text { Simple payback } \\
\text { period }\end{array}$ & Year & 18.34 & 5.43 \\
NPV (7.17\%) & BDT & - & 1396221.51 \\
NPV (8.4\%) & BDT & - & 1140753.18 \\
NPV (8.61\%) & BDT & - & 1100723.15 \\
NPV (10.29\%) & BDT & - & 812889.27 \\
NPV (15.05\%) & BDT & - & 230698.86 \\
IRR & Percentage & 1 & 18 \\
& (\%) & & \\
\hline
\end{tabular}

Source: survey data

NPV was calculated by bringing all the cost and revenue to the year zero based on the expected project life with various deposit and lending interest. The deposit and lending interests were collected from the Bangladesh Bank websites (Bangladesh Bank). The last five years' interests were considered to find out NPV. Internal Rate of Return (IRR) is the discount rate that makes the net present value zero. For a project to be viable, shorter payback period and higher NPV and IRR are desirable. In this analysis it was found that $100 \%$ equity investment was not suitable for returning the investment in the shortest period of time also the NPV and IRR were low for this situation. However, with $50 \%$ to $70 \%$ credit, the project payback period, NPV and IRR were satisfactory to run the project.

\section{5. $\mathrm{CO}_{2}$ emission reduction}

Solar water pumping has numerous advantages, for instance, no cost for fuel and maintenance, no noise and pollution for the environment compare to the conventional fuel. Solar energy is also particularly appropriate in enabling low carbon development in developing countries like Bangladesh. Additional benefits installing a solar power system in irrigation can reduce carbon footprint. Unlike traditional sources of electricity from the grid, solar energy is green, clean and renewable. In use solar panels release no greenhouse gases and they don't pollute the air. There are two alternative sources are available for irrigation in Bangladesh other than solar energy. These are grid electricity and diesel fuel. A 10 hp pump with 07 hours' operation time per day was considered for the calculation for emission comparison as stated in section 4. From Table 5, it can be seen that about $2566 \mathrm{~kg}$ of $\mathrm{CO}_{2}$ is being emitted from grid based irrigation and this value for diesel based irrigation is around $42 \mathrm{~kg}$ per day compared to zero $\mathrm{CO}_{2}$ emission from solar pumping.
Solar energy thus can help to mitigate carbon emissions by replacing more carbon intensive sources of heat and power. The amount of emissions mitigated depends on the amount of conventional heat or power that is displaced, the carbon intensity of the displaced energy sources, and the amount and type of energy that is consumed in manufacturing, installing and operating the solar energy system.

Table 5

$\mathrm{CO}_{2}$ emission in equivalent system

\begin{tabular}{lll}
\hline Parameter & Unit & Value \\
\hline Solar energy & Kg/day & 0 \\
Grid electricity & Kg/day & 2566.24 \\
Diesel fuel & Kg/day & 42.88 \\
\hline
\end{tabular}

\section{Conclusion}

Solar irrigation system is a blessing to the farmer where grid electricity supply is not sufficient. According to the field visit, it was found that $10 \mathrm{hp}$ pump was capable to cultivate about 16.1 hectares' land. The average efficiency of the systems was $16.52 \%$ while average operating time per day was quite satisfactory as well. The initial cost of the project was high but the maintenance cost was reasonably low. From the analysis of the project of Grameen Shakti, it was found that the payback period and IRR were 5.50 years and $18 \%$ respectively. Solar irrigation is still quite new in Bangladesh. Proper policy and financial subsidies should be implemented by the government to popularize the project within the country.

\section{Acknowledgments}

Authors are indebted to Rajshahi University of Engineering and Technology (RUET) for providing all sorts of support throughout the research work. Grateful acknowledgements are extended to the Grameen Shakti, Bangladesh and the owners of the systems for their help during data collection.

\section{References}

Bangladesh. "Agriculture in Bangladesh." Retrieved November 20, 2015, from https://en.wikipedia.org/wiki/Agriculture_in_Bangladesh.

Bangladesh Agriculture at a Glance. "Ministry of Agriculture, Government of the People's Republic of Bangladesh." Retrieved June 24, 2014, from http://www.moa.gov.bd/statistics/bag.htm.

Bangladesh Bank, C. B. o. B. "Investment Rates." Retrieved May 19, 2014, from https://www.bb.org.bd/.

Bangladesh Power Development Board (BPDB). Retrieved June 24, 2014, from http://www.bpdb.gov.bd/bpd.

Hayden, K. Electricity and development-the Asian perspective. Proceedings of the Asian Regional Workshop on Electricity and Development: Asian Institute of Technology, Thailand. ISBN. 
Citation: Hoque, N., Roy, A., Beg, M.R.A. and Das, B.K. (2016) Techno-Economic Evaluation of Solar Irrigation Plants Installed in Bangladesh.. Int. Journal of Renewable Energy Development, 5(1), 73-78, doi.org/10.14710/ijred.5.1.73-78

P a g e 178

Hoque, N. and S. Kumar (2013). Performance of photovoltaic micro utility systems. Energy for Sustainable Development 17(5), 424-430.

IDCOL. Infrastructure Development Company Limited Bangladesh "IDCOL plans to develop Solar irrigation Pump." Retrieved January 12, 2014, from http://www.idcol.org/.

Islam, M. R., M. R. Islam, MRA Beg (2008). Renewable energy resources and technologies practice in Bangladesh Renewable and Sustainable Energy Reviews 12(2), 299-343.

Legros, G. and W. H. Organization (2009). The energy access situation in developing countries: a review focusing on the least developed countries and Sub-Saharan Africa, World Health Organization.

Lipu, M. S. H. and T. Jamal (2013). Techno-economic Analysis of Solar Concentrating Power (CSP) in Bangladesh. International Journal of Advanced Renewable Energy Researches (IJARER) 2(5).

Mahlia, T., J. Yong, A. Safari (2012). Techno-economic analysis of palm oil mill wastes to generate power for grid-connected utilization. Energy Education Science and Technology Part A: Energy Science and Research 28(2), 1111-1130.
Mekhilef, S., S. Faramarzi, R. Saidur, Z Salam (2013). The application of solar technologies for sustainable development of agricultural sector. Renewable and Sustainable Energy Reviews 18, 583594.

Mekhilef, S., R. Saidur, A. Safari, W. Mustaffa (2011). Biomass energy in Malaysia: current state and prospects. Renewable and Sustainable Energy Reviews 15(7), 3360-3370.

Odeh, I., Y. Yohanis, B. Norton (2006). Economic viability of photovoltaic water pumping systems. Solar energy $\mathbf{8 0}(7)$ 850-860.

Power Division. Ministry of Power, E. a. M. R. Government of the Peoples Republic of the Bangladesh. Retrieved May, 2014, from http://www.powerdivision.gov.bd.

Purohit, P. (2007). Financial evaluation of renewable energy technologies for irrigation water pumping in India. Energy Policy 35(6), 3134-3144.

Roy, A., W. Islam (2015). Prospect of Solar Pumping in the Northern Area of Bangladesh. American Journal of Renewable and Sustainable Energy 1(4), 172-179.

Solar-Powered Pumps Reduce Irrigation Costs in Bangladesh. THE WORLD BANK, Working for a World Free of Poverty. Retrieved November 20, 2015, from http://www.worldbank.org/en/results/2015/09/08/solarpowered-pumps-reduce-irrigation-costs-bangladesh. 